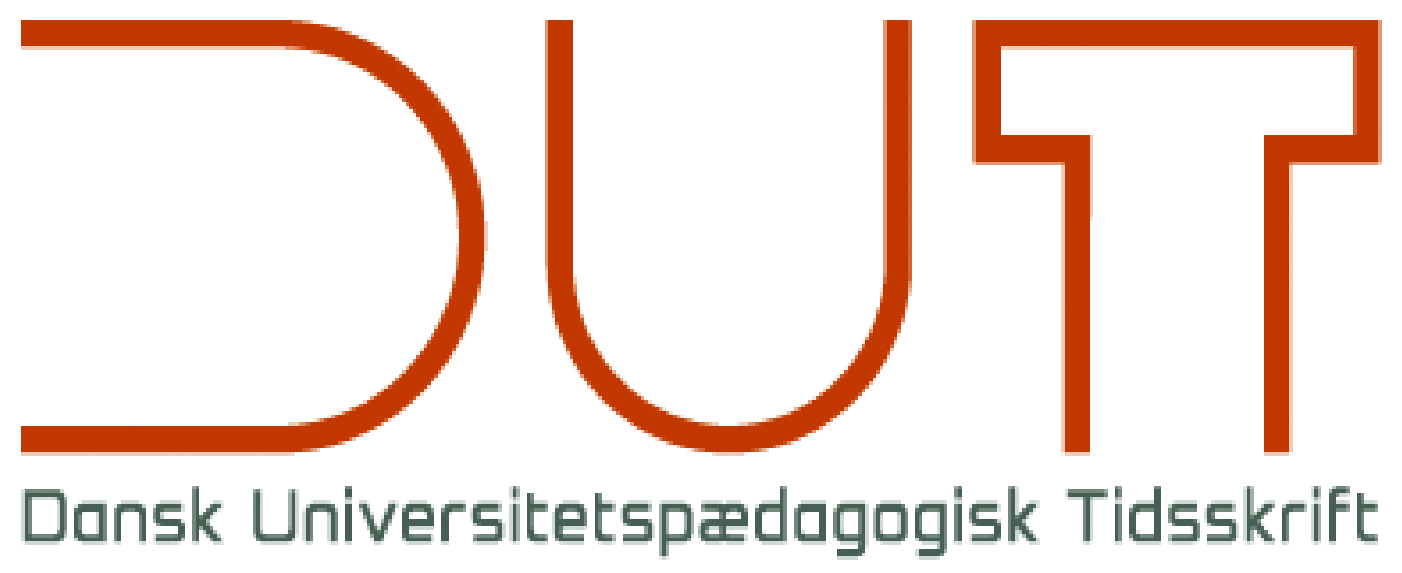

Tema

Ledelse, udvikling og overlevelse på universitetet

Årgang 12 nr. 22 / 2017

Titel

Læring i Modvind: Hvordan forbedrer man de studerendes præstation i fag, som de typisk opfatter som svære og kedelige?

Forfatter

Carina Saxlund Bischoff

Sidetal

$21-34$

Udgivet af

Dansk Universitetspædagogisk Netværk, DUN

URL

> http://dun-net.dk/

Betingelser for brug af denne artikel

Denne artikel er omfattet af ophavsretsloven, og der må citeres fra den. Følgende betingelser skal dog være opfyldt:

- Citatet skal være i overensstemmelse med "god skik“

- Der må kun citeres „i det omfang, som betinges af formålet"

- Ophavsmanden til teksten skal krediteres, og kilden skal angives ift. ovenstående bibliografiske oplysninger. 


\section{Læring i Modvind: Hvordan forbedrer man de studerendes præstation i fag, som de typisk opfatter som svære og kedelige?}

Carina Saxlund Bischoff, ph.d., lektor, studieleder, Institut for Samfund og Globalisering, Roskilde Universitet, ISG

\section{Reviewet artikel}

Hvordan forbedrer man de studerendes præstationer i fag, som de ikke i udgangspunktet er positivt indstillet overfor, og hvor en stor del oplever stoffet som vanskeligt? Hvad kan man håbe at opnå med kursusforbedringer, og hvilken betydning har forskellige typer studieaktivitet for de studerendes læring? Undersøgelsen, som artiklen bygger på, er baseret på data fra to årgange på RUCS samfundsvidenskabelige basisuddannelse, som har fulgt det obligatoriske kursus i kvantitativ metode. Datagrundlaget udgøres af evalueringer, observeret kursusaktivitet på fagets hjemmeside samt detaljerede eksamensbedømmelser. Først undersøges effekterne af kursusforbedringer, hvor det ses, at en markant øget tilfredshed med kurset ikke som forventet medforte en stigning i andelen, som bestod eksamen. Effekten på det faglige niveau var stærkt positiv, men polariseret, 'toppen' blev således løftet markant mere end 'bunden'. De studerendes forberedelsestid var generelt lav og kun svagt korreleret med deres eksamenspræstation. Dog ses det, at studerende, som forbereder sig mere end fem timer om ugen, stort set er sikre på at bestå. Endelig ses det, at deltagelse i undervisningen (forelæsninger) og i endnu højere grad selvstændigt arbejde med øvelsesmaterialet har en stærkt positiv effekt på præstationen ved eksamen. At motivere de studerende til højere studieaktivitet synes således at være den vigtigste udfordring fremover.

\section{Introduktion}

Kvantitativ metode har i de senere år fået en fast og større plads på samfundsvidenskabelige uddannelser i Danmark. Statistiske analyser indgår i rapporter og videnskabelige arbejder, som spiller ind på debatter såvel som beslutningsprocesser i politik og forvaltning. Kandidater på det samfundsvidenskabelige område forventes derfor ofte at kunne læse og udføre den type analyser for deres arbejdsgivere. Aftagerpaneler for samfundsvidenskabelige uddannelser, herunder Roskilde Universitet (RUC), har således i flere tilfælde bedt om en oprustning på den front. De studerende modtager dog ikke nødvendigvis oprustningen på den kvantitative front med stor begejstring alle steder. En undersøgelse blandt fjerde semester studerende på den samfundsvidenskabelige bacheloruddannelse i 2015 på RUC viste, at $72 \%$ af de stude- 
rende havde overvejende negative forventninger til det obligatoriske kursus i kvantitativ metode ved kursusstart ${ }^{1}$. Muligvis kan en generelt større forkærlighed for humanistiske end naturvidenskabelige fag fra tiden før universitetet bidrage til at forklare den negative indstilling. I mødet med de studerende fortæller undervisere i faget om en ret udbredt grad af 'talforskrækkelse' blandt de studerende. De oplever, at det kræver en særlig indsats at motivere dem til at overvinde denne barriere. Forskning i læring peger utvetydigt på studerendes motivation og selvopfattelse som vigtige determinanter for læring (DeHaan, 2005), og kvantitativ metode er således en særlig pædagogisk udfordring på uddannelser, hvor de studerende ikke er matematisk orienterede. Det er desuden en interessant case på, hvordan man kan arbejde med at højne niveauet for studerende, der ikke automatisk er topmotiveret for at lære.

Udover motivation og faglige forudsætninger for at arbejde med faget bør det også nævnes, at den brede optagelse på uddannelser kan bidrage til en særlig udfordring i forhold til at fremme gode præstationer. De senere år har adgangskvotienten for de samfundsvidenskabelige bacheloruddannelse på RUC nemlig ligget under middel, og masseuniversitetets udfordringer er således til stede her (se bl.a. DUT-tema om masseuniversitetets udfordringer, Årg. 10, Nr. 18 (2015)). Studier har vist, at adgangsgivende karakterer har betydning for præstation på de medicinske uddannelser (O'Neill et al., 2013), og der er ikke nogen grund til at tro, det ikke også gør sig gældende på andre fag. Det brede optag på RUCs samfundsvidenskabelige basisuddannelse kan betyde, at studerende, der kommer ind med lave karakterer fra gymnasiet, kan have vanskeligt ved at præstere godt.

I denne artikel stilles to typer spørgsmål, som er centrale for undervisningsplanlægningen på universiteter, der står med denne type udfordringer. Det første handler om, hvad man kan opnå ved bedre kursustilrettelæggelse. Vil man kunne øge de studerendes tilfredshed og vende negative forventninger til en positiv oplevelse af kurset? Vil man kunne øge de studerendes læring og mindske andelen af studerende, der dumper til eksamen? Det andet sæt spørgsmål handler om, hvilken betydning individuelle forskelle i form af forberedelse og deltagelse i undervisning har for de studerendes præstation til eksamen? I de følgende afsnit vil casen (kurset og ændringerne i dette) først blive præsenteret og det grundlæggende undersøgelsesdesign blive beskrevet. Derefter vil der være en præsentation af de data og indikatorer, som anvendes i analysen.

\footnotetext{
${ }^{1}$ De studerende blev bedt om at vælge ord, som bedst beskrev deres forventninger til kurset. $72 \%$ valgte ordparrene svært-nødvendigt eller kedeligt-hårdt, mens de resterende $28 \%$ valgte spændende-nyttigt eller sjovt-udfordrende.
} 


\section{Case(s), undersøgelsesspørgsmål og forskningsdesign}

Casen, som studiet her tager udgangspunkt i, er et kursus i kvantitativ metode på den samfundsvidenskabelige bacheloruddannelse på RUC. Undersøgelsen anvender to forskellige undersøgelsesdesign for at besvare spørgsmålene. Det første er et 'naturligt eksperiment'-design, hvor effekten af en observeret ændring undersøges ved at sammenligne forhold før og efter ændringen (se fx Gerring, 2004). Med udgangspunkt i kursusændringer mellem 2014 og 2015 undersøges den aggregerede effekt af disse på de studerendes kursustilfredshed og deres præstation ved eksamen. Den anden del af undersøgelsen er en tværsnitsundersøgelse af 2015-årgangen, hvor der bliver set på forskellige studieaktiviteters effekt på eksamenspræstationen. I det følgende beskrives kurset og de ændringer, som blev iværksat, mens spørgsmål om data og indikatorer vil blive behandlet i næste afsnit.

Kvantitativ metode blev afholdt for første gang som et 5 ECTS obligatorisk kursus på den samfundsvidenskabelige bacheloruddannelse på RUC i 2014. Kurset inkluderede 12 forelæsninger af halvanden time og 12 gange med opfølgning (øvelsestimer) af to timers varighed. Ved den interne evaluering ved kursets afslutning udtrykte de involverede undervisere grundlæggende tilfredshed med kursets indhold og afvikling. Eksamensresultaterne og senere studenterevalueringerne gav dog anledning til, at den positive opfattelse af forløbet blev taget op til revision. Cirka en tredjedel af de studerende bestod ikke eksamen, og eksaminatorerne var enige om, at det faglige niveau generelt var lavt. En overvældende andel af de studerende var derudover særdeles utilfredse med kurset. Det gjaldt både oplevelsen af undervisningens kvalitet, hvor ca. $60 \%$ var utilfredse med formidlingen til forelæsningerne, samt arbejdsbyrden, hvor 50 \% mente, at omfanget af materialet, der skulle nås til hver gang, var for stort. Særligt oplevelsen af arbejdsbyrden er vist at hænge sammen med læring (se Lizzio et al. 2002), så denne opfattelse er ikke uvæsentlig. Så mange som 80 \% af respondenterne mente ikke, at undervisningen i tilstrækkelig grad havde rustet dem til eksamen. Samtidigt fremgik det, at kun omkring $50 \%$ af de studerende havde læst over halvdelen af det obligatoriske pensum, og kun omkring $25 \%$ angav at have læst mellem 75-100 \%.

Der blev derfor gjort en indsats for at forbedre kurset, som skulle gentages i foråret 2015. Vi fastholdt den grundlæggende hensigt med kurset: at gøre de studerende i stand til selvstændigt at anvende kvantitative metoder samt at kunne foretage en kritisk vurdering af kvantitative analyser og de konklusioner, der drages på grundlag af dem. I undervisning såvel som ved eksamen blev der lagt vægt på anvendelse og vurdering snarere end gengivelse af pensum, idet vi søgte at tilskynde til 'dybe' tilgange til læring snarere end 'overfladiske' (se Biggs, 2003). Den fælles 'skabelon' for forelæsninger bestod først af kort præsentation af en type spørgsmål, de studerende skulle lære at besvare, dernæst i en indføring i de centrale begreber, teorier og metoder nødvendige for at besvare den type spørgsmål og endelig et eksempel (eller flere) på 
den relevante type analyse i praksis. Ved øvelsestimerne blev de stillet nogle konkrete opgaver, hvor de skulle anvende teori og begreber fra dagens pensum, praktisk udføre analyser og endelig forholde sig kritisk til resultatet. Eksamensspørgsmålene (som efter første år også indgik som øvelsesmateriale) var lavet således, at de ikke kunne besvares ved simpel gentagelse af pensum. I stedet blev de studerende præsenteret for undersøgelser, de skulle vurdere, eller konkrete spørgsmål, de skulle besvare ved at udføre en analyse eller redegøre for, hvordan de ville tilrettelægge en analyse. Der blev med andre ord ikke spurgt om for eksempel 'hvilke forhold skal man være opmærksom på ved formulering af spørgeskemaspørgsmål?', 'hvordan beregnes et konfidensinterval?' eller 'hvad er R²?', hvor spørgsmålet kunne besvares ved simpel gengivelse af pensum. I stedet blev de studerende bedt om at vurdere nogle konkrete eksempler på spørgeskemaspørgsmål eller selv formulere nogle, identificere usikkerheden på estimater oplyst i en undersøgelse eller f.eks. undersøge en given sammenhæng, som fordrer kendskab til regressionsanalyse og viden om $\mathrm{R}^{2}$. Spørgsmålene angav med andre ord ikke, hvilken specifik del af pensum, der skulle anvendes, og de studerende skulle demonstrere kendskab ved at bringe relevant viden $\mathrm{i}$ anvendelse $\mathrm{i}$ forhold til løsning af konkrete problemer.

Forandringerne fra 2014 til 2015 havde til formål at skabe en bedre 'alignment', dvs. Overensstemmelse, mellem fagets målsætninger, kursusgangenes indhold og eksamen (Biggs og Tang, 2011). Derudover ønskede vi at styrke kommunikation af læringsmål til de studerende samt at tydeliggøre succeskriterierne i forhold til eksamen, som også er vist at have stor betydning for læring (se bl.a. diskussion i Qvortrup \& Keiding, 2014). Konkret blev der således 1) skabt klarere sammenhæng mellem forelæsningerne og de efterfølgende øvelser, 2) nedfældet klare læringsmål (teoretiske og praktiske færdigheder) for hver eneste kursusgang, som blev indskrevet i undervisningsplanen og 3) indføjet eksamenssæt fra året før i øvelserne, så de studerende kunne se, hvad de kunne forvente at møde til eksamen. Af direkte pædagogiske tiltag kan nævnes 1) styrkelse af eksemplificering i forelæsningerne, således at teoretisk fremstilling altid blev kædet sammen med praktisk anvendelse og vurdering af analyseresultater, 2) omdeling af spørgeskema til de studerende ved første kursusgang. Deres besvarelser blev samlet i et datasæt, som indgik direkte i øvelserne. Ideen var at øge de studerendes fortrolighed med og interesse for både spørgeskemakonstruktion, variable, cases og datasæt ved at sætte dem til at analysere spørgsmål og data, de selv havde været med til at generere samt 3) samling af øvelser og instruktioner i anvendelse af statistikprogrammet i et kompendium, så selvstændigt arbejde med øvelserne blev lettere at overskue. Af resursemæssige årsager og for at bringe kurset $\mathrm{i}$ overensstemmelse med de normer om undervisning og læsning, der var gældende på andre kurser, blev pensum reduceret med $10 \%$ og antal undervisningsgange fra 12 til 10 , tid til opfølgning og øvelser fra to til halvanden time og bemanding til øvelser fra tre til to per 80 studerende. 


\section{Data og indikatorer}

Datagrundlaget for analyserne er kursusevalueringer, registreret kursusaktivitet på kursushjemmesiden samt eksamensbedømmelser for de to årgange 2014 og 2015 på den samfundsfaglige bacheloruddannelse. Data og indikatorer indgår i beskrivelser af tilfredshed med kurset og forskellige former for kursusaktivitet og eksamenspræstationer såvel som i analyser af sammenhænge mellem kursusaktivitet og eksamenspræstation. Nedenfor præsenteres data og de indikatorer, som anvendes.

\section{Kursusevalueringer}

Kursusevalueringerne fra de to år anvendes som informationskilde om forskel på de studerendes tilfredshed med undervisningen og kurset som helhed såvel som deres studieaktivitet (kun 2015). Der er dog nogle forskelle mellem de to års evalueringer, som har betydning for sammenligneligheden af de studerendes vurderinger af kurset. For det første er der forskelle i de stillede spørgsmål. Betydning af disse diskuteres direkte i forbindelse med anvendelsen af evalueringerne (se nedenfor). For det andet var der flere respondenter i 2015 end i 2014. 175 besvarelser i 2015 (42 \% af de tilmeldte) sammenlignet med 101 i 2014 (24 \% af de tilmeldte), som sikkert hænger sammen med, at evalueringen i 2014 først blev iværksat efter eksamen (i sommerferien) og ikke ved (og en uge efter) sidste kursusgang som i 2015. Både antal besvarelser og tilskyndelsen til at evaluere sidste undervisningsgang betyder, at 2015 stikprøven sandsynligvis er mere repræsentativ for årgangen. Der er også en reel risiko for, at evalueringerne i 2014 var påvirkede af den høje dumpeprocent (se nedenfor), idet evalueringen fandt sted efter eksamensresultaterne var meldt ud.

Ved brugen af evalueringen for 2015 som informationskilde om de studerendes deltagelse i undervisningen og forberedelsestid er det vigtigt at være opmærksom på, at stikprøven ikke er repræsentativ for alle kursustilmeldte. For at undersøge repræsentativiteten undersøgte jeg, om der var forskel på de 151, som evaluerede, og hele årgangen (396) med hensyn til deres eksamenspræstation. En sammenligning af andel point ud af totalt mulige, som blev opnået ved eksamen, viser, at de 151 opnåede 58 $\%$ af det maximalt mulige antal point, mens årgangen som helhed opnåede 51 \% (se nedenfor om eksamensbedømmelser). Desuden var der $10 \%$ færre, der ikke bestod ved eksamen end for hele årgangen. De 151 er således ikke repræsentative, men udgør en gruppe, som har gjort det bedre end gennemsnittet. Denne type selektionsbias ('trunkering') betyder, at vi generelt kan forvente at se svagere sammenhænge mellem de uafhængige og afhængige variable i analyserne (Collier \& Mahoney, 1996).

\section{Observeret kursusaktivitet}

Det selvrapporterede aktivitetsniveau i evalueringen suppleres med observeret aktivitet på kursussiden på moodle-platformen i 2015. Der er således lavet udtræk på, hvorvidt og hvornår de studerende har tilgået de materialer, som er centrale for undervisningsforløbet, dvs. forelæsningsslides og øvelsesmaterialer. Antal visninger og 
downloads af materialer bliver brugt som en indikator på kursusaktivitet. Da det er normen, at studerende, som deltager i forelæsninger og de følgende opfølgninger, tilgår forelæsningsslides, er antal visninger og downloads en rimelig god indikator for deltagelse, selv om den ikke er lige så præcis, som en direkte registrering ved undervisningen ville være. Tallene overestimerer den faktiske aktivitet en smule, hvilket skyldes at hvis en studerende går ind to eller flere gange og downloader et givent materiale, så registreres de for hver gang, de downloader. Det har jeg forsøgt at korrigere for, men der er en mindre 'overestimerings-bias' i indikatoren. Det samme gælder for materiale, som er nødvendigt for at arbejde med øvelserne. Indikatoren for deltagelse i forelæsninger er dog baseret på tre centrale forelæsninger, og der er derfor større usikkerhed for denne indikator end for den øvelsesaktivitet, som er baseret på de syv første ud af 10.

\section{Eksamensbedømmelser}

Der blev foretaget en særlig præcis måling af de studerendes præstation til eksamen, hvor bedømmerne gav point for hver enkelt opgave i sættet, som havde et maksimalt antal mulige point. Dette blev gjort for at få information om, hvilke styrker og svagheder, de studerende havde, og sikre en ensartet bedømmelse. Eksamen blev bedømt med 'bestået'/'ikke-bestået'. Eksaminatorerne blev bedt om at indsende deres bedømmelser (excelark) til den kursusansvarlige, der dog modtog færre i 2014 (150 i alt) end i 2015 (396 i alt). Måling af præstation til eksamen er derfor antal point (ud af de maksimalt mulige), som de studerende opnåede. Det er dog vigtigt at bemærke, at andelen af 'ikke-beståede' for de indsendte bedømmelser lå hhv. 8 og 9 procentpoint under det samlede resultat for årgangen i 2014 (32 \%) og 2015 (38 \%). Det er sandsynligt, at det skyldes, at eksaminatorerne ikke har gjort sig den ulejlighed at lave en fuldkommen bedømmelse med point per opgave, når det har været tydeligt, at en opgave ikke ville bestå (fx fordi kun første opgave er besvaret). Det betyder, at der vil være en generel overvurdering af pointniveauet for gruppen af ikke-beståede, som dog kan forventes at være ens for de to år.

Karakteren af eksamen har stor betydning for, hvorvidt vi kan forvente, at eksamenspræstationen reflekterer de studerendes faglige læring. Den femtimers skriftlige eksamen indeholdt begge år et bredt batteri af spørgsmål, hvor alle hovedkategorier inden for pensum var repræsenteret, og der blev prøvet i de vigtigste statistiske metoder.

\section{Effekt af kursusforbedringer på tilfredshed og eksamenspræstation}

\section{Effekt af kursusforandringerne på de studerendes tilfredshed}

Den første del af analysen retter sig mod effekten af kursusreformen 2014 til 2015 på de studerendes tilfredshed med kurset. Spørgsmålene ved evalueringen af kurset i 2014 afveg som nævnt fra dem, som blev brugt i 2015, så det er ikke muligt at lave en 
en-til-en-sammenligning på alle relevante aspekter. Der er dog to sæt spørgsmål vedrørende den formidlingsmæssige og pædagogiske indsats til forelæsningerne og øvelserne (opfølgning), som er sammenlignelige; ordlyden er ikke den samme, men det er en rimelig antagelse, at de studerende ville respondere ret ens på de to spørgsmål, som desuden havde de samme svarkategorier.

TABEL 1.

EVALUERING AF UNDERVINSINGEN I KVANTITATIV METODE

\begin{tabular}{|c|c|c|c|c|c|}
\hline & $\begin{array}{l}\text { Meget/yderst } \\
\text { tilfredsstillende }\end{array}$ & \multicolumn{3}{|c|}{ - } & $\begin{array}{c}\text { Meget/yderst } \\
\text { utilfredsstillende }\end{array}$ \\
\hline & 1 & 2 & 3 & 4 & 5 \\
\hline \multicolumn{6}{|l|}{ Forelæsninger } \\
\hline $\begin{array}{l}\text { 2014: "Hvordan har du oplevet } \\
\text { den mundtlige formidling ved de } \\
\text { forelæsninger i kvantitativ metode } \\
\text { du har deltaget i?" }\end{array}$ & 2 & 10 & 26 & 35 & 28 \\
\hline $\begin{array}{l}2015 \text { : "Hvad er din bedømmelse } \\
\text { af forelæserens generelle } \\
\text { pædagogiske niveau i dette fag?" }\end{array}$ & 21 & 52 & 15 & 9 & 3 \\
\hline \multicolumn{6}{|l|}{ Øvelser } \\
\hline $\begin{array}{l}\text { 2014: "Hvordan har du oplevet } \\
\text { den mundtlige formidling ved de } \\
\text { opfølgninger i kvantitativ metode } \\
\text { du har deltaget i" }\end{array}$ & 10 & 32 & 25 & 18 & 15 \\
\hline $\begin{array}{l}\text { 2015: "Hvad er din bedømmelse } \\
\text { af underviseren/undervisernes } \\
\text { generelle pædagogiske niveau ved } \\
\text { opfølgningerne" }\end{array}$ & 21 & 51 & 20 & 4 & 4 \\
\hline
\end{tabular}

Evaluering af undervisningen til både forelæsninger og øvelser viste, at de studerendes oplevelse af kurset var markant ændret i positiv retning (se tabel 1). Stigningen $i$ andel studerende fra 2014 til 2015, som placerer sig i de to mest tilfredse kategorier, er hhv. $61 \%$ (forelæsninger) og $30 \%$ (øvelser). Som diskuteret i afsnittet om data og metode ovenfor er der forskelle på tidspunktet for evalueringen og antal deltagere, som gør, at vi kan forvente, at der er en negativ bias i evalueringerne for $2014 \mathrm{i}$ forhold til året efter. En del af den positive forandring kan sandsynligvis tilskrives dette. Med dette forbehold in mente synes det dog stadigt markant, at kurset, i de studerendes optik, var blevet tydeligt forbedret i forhold til året før.

\section{Effekt af kursusforbedringer på de studerendes præstation ved eksamen}

På baggrund af de positive evalueringer var den klare forventning, at en meget højere andel af de studerende ville bestå eksamen i 2015 end i 2014. Det kom derfor som en overraskelse, at så mange som $38 \%$ af de studerende, som gik til eksamen, ikke bestod (34 \% af de tilmeldte på kurset). Det var stort set den samme andel ikke-beståede 
som året før. Det er derfor oplagt at studere eksamensbedømmelserne med henblik på at undersøge, om den eneste effekt af kursusændringerne var på de studerendes tilfredshed. Når man sammenligner resultaterne ved eksamen i 2014 med resultaterne ved eksamen i 2015, er det dog tydeligt, at 'kursusreformen' ikke kun havde en effekt på studerendes tilfredshed, men også løftede det faglige niveau. Man kan se, at niveauet ved eksamen målt som andel point af de maksimalt mulige i 2015 var markant højere end året før.

\begin{tabular}{|l|c|c|c|}
\hline TABEL 2. & \multicolumn{2}{|c|}{ PRASTATION VED EKSAMEN 2014 og 2015 } \\
\hline \hline & ANDEL POINT (\%) UD AF MAXIMALT ANTAL MULIGE & \\
& $\mathbf{2 0 1 4}$ & $\mathbf{2 0 1 5}$ & Endring \\
\hline Alle & $40 \%$ & $51 \%$ & $11 \%$ \\
\hline Bestået & $52 \%$ & $66 \%$ & $14 \%$ \\
\hline Ikke-bestået & $24 \%$ & $29 \%$ & $5 \%$ \\
\hline $\mathrm{N}$ & 150 & $396(\mathrm{alle}) / 292(\mathrm{~b} / \mathrm{ib})$ & \\
\hline
\end{tabular}

Det fremgår af tabellen, at når vi sammenligner besvarelserne fra sidste år med i år, så er andelen af rigtige svar steget med 11 procentpoint for hele årgangen. Det er dog samtidigt tydeligt, at der er sket en polarisering, idet de der ikke bestod, ikke er blevet løftet nær så meget, som de der bestod. Gruppen der bestod eksamen (ca. 2/3 af de studerende) har således haft en fremgang på 14 \% i andelen af mulige point, mens de, der dumpede (ca. 1/3), kun har en 5 \% forbedring i forhold til 2014.

Det er muligt, at beskæringen af øvelsestid og bemanding har haft betydning for særligt de svage studerende og kan forklare en del af det manglende løft i niveauet i den lave ende. Det er dog også hensigtsmæssigt at undersøge, om de studerendes eget aktivitetsniveau har haft betydning for eksamensresultatet.

\section{Effekt af individuel studieaktivitet for eksamenspræstation}

Den ovenstående analyse indikerer, at kursustilrettelæggelsen har haft en væsentlig betydning for de studerendes præstation ved eksamen, selv om det ikke ændrede ved beståelsesprocenten. Spørgsmålet er, hvilken rolle de studerendes egen studieaktivitet spiller. På det aggregerede niveau er der flere tegn på, at en del af problemet i 2015 kunne være relateret til manglende deltagelse i undervisning og forberedelse. Hvis de studerende skal følge normen for et 5 ECTS-kursus, som angiver en arbejdsbyrde på 130-150 timer, burde de bruge ca. 10-12 timer om ugen på forberedelse udover deltagelse i selve undervisningen (30 timer) - i de uger, kurset løber. Den gennemsnitlige tid, som de studerende selv angiver at have brugt på forberedelse, var dog kun 3,8 timer om ugen. Kun $21 \%$ af de studerende oplyser at have brugt fem eller flere timer om ugen, mens hele $26 \%$ oplyser at have brugt en time eller mindre om ugen. Mønstret af forholdsvis lav aktivitet understøttes af den observerede aktivitet 
på moodle-kursussiden. Ved at se på antal visninger og downloads af centrale materialer kan man få en indikation af aktivitetsniveauet (se afsnittet om data og metoder). Ved at undersøge visninger og downloads af slides til fire centrale forelæsninger (den 4. 6. og 7. og 9. ud af de 10 afholdte) kunne man se, at kun omkring $60-75 \%$ af årgangen deltog i forelæsningerne. Der var $75 \%$ visninger og downloads til 4. undervisningsgang (sandsynlighedsteori og estimation), $71 \%$ til 6. kursusgang (sammenhæng af kategoriske variable), $62 \%$ til 7. kursusgang (regressionsanalyse) og $59 \%$ til 9 . kursusgang (regressionsanalyse). En anden vigtig indikator for aktivitet er arbejde med øvelsesopgaver, som direkte ruster de studerende til eksamen. Ved at se på downloads og visninger af øvelsessvarene til de første syv af de 10 ugentlige øvelser kunne man se at kun 15-30\% af de studerende havde set på øvelsessvarene. Ved sidste kursusgang var andelen steget til 35-60 \%, mens andelen når op på 80-100 \% af alle kursusdeltagere umiddelbart før eksamen. Det er således tydeligt, at selv om der var udbredt tilfredshed med kurset, så var der stadigt et problem med at motivere de studerende til at yde en aktiv indsats i undervisningsforløbet.

I den næste del af analysen vil jeg derfor undersøge, hvilken rolle de studerendes forberedelse og deltagelse i kurset har for deres præstation ved eksamen. Analysen baseres på 151 af de studerende, idet det ikke var muligt at trække information om hele årgangen fra de tre datakilder (evaluering, moodle-side og eksamensbedømmelser), men kun for denne gruppe.

\section{Hvilken betydning har antal timer om ugen brugt på forberedelse?}

Som nævnt blev de studerende bedt om at svare på, hvor mange timer om ugen de anslog at have brugt på at arbejde med kurset udover deres deltagelse i undervisningen. Det minimale antal timer, som blev oplyst, var 0, og det maksimale var 12,5. Når man kører en enkel, bivariat korrelation mellem timers forberedelse og eksamenspræstation, får man en korrelationskoefficient (Pearsons r) på 0,13, som indikerer en meget svag positiv sammenhæng, som dog ikke er signifikant. Ser man på en grafisk fremstilling af sammenhængen mellem de to variable, tegner der sig dog et klarere mønster. 


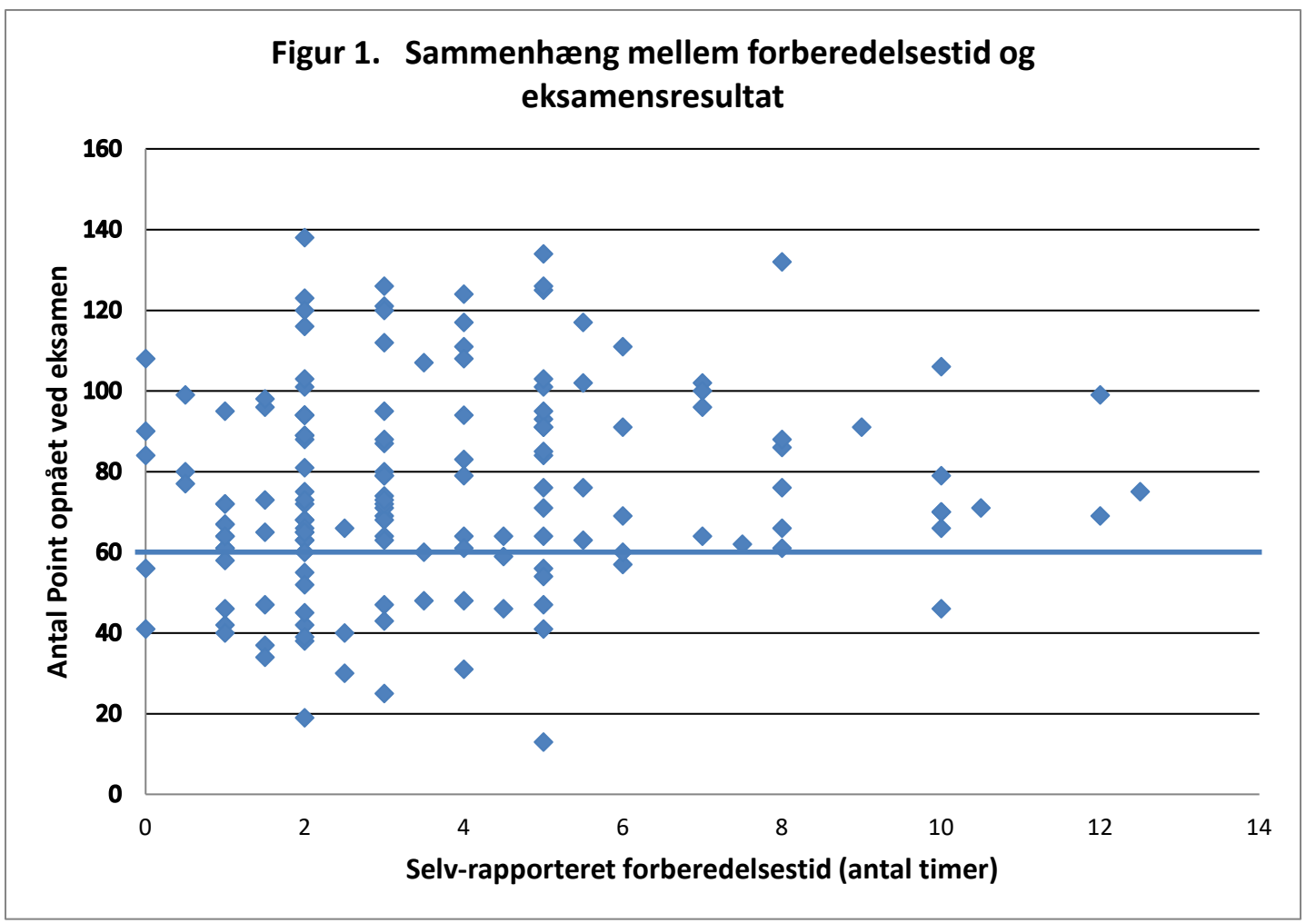

Der er ikke nogen klar sammenhæng mellem antal timer brugt om ugen og præstation ved eksamen (point opnået ved eksamen) for studerende, som angiver at have brugt fem timer eller mindre om ugen. Der er flotte præstationer blandt studerende, som tilsyneladende kun har lagt meget lidt tid i kurset, og det virker derfor sandsynligt, at det primært er forskel i evner og evt. tidligere læring, som er udslagsgivende - eller simpelthen at en del studerende har lagt timerne på at arbejde med stoffet efter kursets (og evalueringens) afslutning. Det er dog også meget tydeligt, at der blandt de studerende, som har brugt minimum fem timer om ugen på at arbejde med stoffet $\mathrm{i}$ den periode, kurset løb, er en klar tendens til, at de klarer sig godt til eksamen. Grænsen mellem at bestå og ikke-bestå blev ved eksamen sat til omkring 60 point (den horisontale linje på figuren). Man kan således se, at med en forberedelsestid på over fem timer om ugen, var det stort set givet, at man ville bestå eksamen. Forberedelse over et bestemt antal timer fjernede således de dårligste præstationer. Det kan således konstateres, at forberedelsestiden helt klart har en effekt, selv om effekten af den, som målt her, ikke er lineær.

\section{Hvilken betydning har deltagelse i kursusaktiviteterne?}

Det næste spørgsmål er, hvorvidt deltagelse i kursusaktiviteterne har en effekt. Der er ikke på individniveau angivelse af deltagelse i forelæsninger og øvelser i evalueringen. Derfor er den eneste mulighed for at indsamle data at anvende den registrerede aktivitet på kursets hjemmeside (moodle), som beskrevet ovenfor. 


\section{Deltagelse i forelæsninger}

Der blev udvalgt tre centrale forelæsninger (4,6 og 7), og det blev undersøgt, i hvilket omfang de studerende deltog i disse ved at se på om de downloadede forelæsningsslides før eller på selve dagen for forelæsningen.

Tabel 3.

Deltagelse i centrale forelæsninger og eksamenspræstation (point 0-138)

\begin{tabular}{|l|r|r|r|r|}
\hline & \multicolumn{2}{|c|}{ Eksamenspræstation i point (0-138) } & \\
Detagelse i centrale forelæsninger & Gns. & \multicolumn{1}{c|}{ Median } & \multicolumn{1}{c|}{ Std. Afv. } & N \\
\hline Ikke deltaget i centrale forelæsninger & 63,0 & 62,5 & 14,4 & 12 \\
\hline Deltaget i 1 central forelæsning & 74,0 & 71,0 & 29,6 & 23 \\
\hline Deltaget i 2 centrale forelæsninger & 73,7 & 71,0 & 28,4 & 47 \\
\hline Deltaget i 3 centrale forelæsninger & 80,5 & 77,0 & 22,7 & 69 \\
\hline \hline Total & 76,0 & 72,0 & 25,5 & 151 \\
\hline
\end{tabular}

Der synes at være en klar sammenhæng mellem deltagelse i de tre centrale forelæsninger og præstation ved eksamen. Der er cirka 17 points forskel på de studerende, som slet ikke var til stede ved nogle af de tre forelæsninger, og de som var til stede ved alle tre. Der kan dog ikke spores nogen forskel på studerende, der har deltaget i blot en eller to af disse forelæsninger. Antal personer $(\mathrm{N})$ i de enkelte kategorier er dog lavt, og forskellen mellem dem er ikke signifikant (bonferroni korrektion anvendt).

Tabel 4. Deltagelse $\mathrm{i}$ centrale forelæsninger $\mathrm{og}$ eksamenspræstation (point 0-138)

\begin{tabular}{|l|r|r|}
\hline Deltagelse & Gns. Point & \multicolumn{1}{|c|}{ N } \\
\hline Ikke deltaget i alle centrale forelæsninger & 72,2 & 82 \\
\hline Deltaget i alle centrale forelæsninger & 80,5 & 69 \\
\hline Forskel $i$ antal point & $8,3 *$ & \\
\hline * signfikant på 0,05 niveau & & \\
\hline
\end{tabular}

Hvis man i stedet (se tabel 4.) ser på forskellen mellem de, som har deltaget i alle centrale forelæsninger, og de som ikke har (to næsten lige store grupper), så er der en forskel på lidt over 8 point, og forskellen i gennemsnitlig præstation er signifikant.

\section{Selvstændigt arbejde med øvelser}

Den næste kursusaktivitet er aktivt selvstændigt arbejde med øvelserne. De studerende arbejder med øvelserne til undervisningen, men kan godt deltage i disse øvelser uden at downloade svarene, som bliver lagt op på kursushjemmesiden efter øvelsesgangen. Hvis de efter øvelserne gik ind og hentede de korrekte øvelsessvar inden for to uger efter den pågældende øvelsesgang, bliver de her registreret som havende arbejdet selvstændigt med øvelserne. Det betyder således ikke, at man ikke har arbejdet 
med øvelser i det hele taget før eksamen, hvis man ikke har downloadet øvelsessvarene. Man har blot ikke har gjort det i forbindelse med undervisningen. I forhold til deltagelse i forelæsninger kan man se, at andelen af studerende, som har arbejdet med øvelserne efter undervisningen, er relativt lille.

TABEL 5.

Selvstændigt arbejde med øvelser og eksamenspræstation (point 0-138)

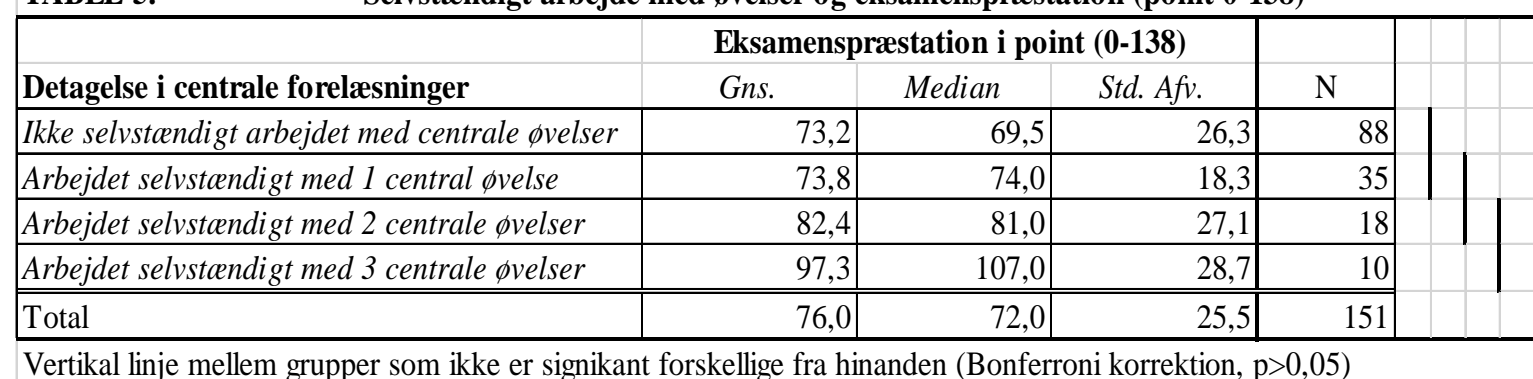

Ser man på sammenhængen mellem arbejdet med øvelsesmaterialet og præstation til eksamen, er mønstret tydeligt, og resultatet er statistisk signifikant. Studerende, som har arbejdet med øvelserne, klarer sig gennemsnitligt markant bedre end studerende, som ikke har. For de studerende, som har arbejdet med alle tre centrale øvelser under kursusforløbet, ligger den gennemsnitlige score omkring 24 point over de, som ikke har arbejdet med øvelserne eller kun gjort det en gang, og forskellen er signifikant.

\section{Sammenhæng mellem forberedelsestid og kursusaktivitet}

Et centralt spørgsmål er, om der faktisk også er en sammenhæng mellem aktiv deltagelse og forberedelsestid, som kunne gøre det vanskeligt at skille effekten af deltagelse i undervisningsaktiviteterne fra effekten af den anvendte tid til forberedelse. Det er dog ikke tilfældet. Aktiv deltagelse i forelæsningerne for denne gruppe er kun meget lavt korreleret med den selvrapporterede forberedelsestid (Pearsons $r=0,04$ og ikke signifikant). Og ser vi på sammenhæng mellem forberedelsestid og selvstændigt arbejde med øvelserne, så er korrelationen kun svagt højere (Pearsons $r=0,11$ og stadigt ikke signifikant). Det at deltage i undervisningen og bruge tid på forberedelse hænger altså ikke tæt sammen. Dette resultat er på linje med resultatet af Herrmann et al.s undersøgelse af sammenhæng mellem undervisning og studieaktivitet (Herrmann et al. 2015).

I den samlede vurdering af disse resultater er det nødvendigt at genkalde sig, at stikprøven består af studerende, der generelt er mere aktive og klarer sig bedre til eksamen end årgangen som helhed. Konsekvensen af denne skævhed for resultatet er en såkaldt dæmpende effekt, hvor sammenhængen mellem de uafhængige og afhængige i stikprøven er svagere, end den ville være, hvis vi havde haft en repræsentativ stikprøve, hvor den fulde variation i den afhængige variabel (eksamensresultat) var 
repræsenteret (se Collier \& Mahoney, 1996). Den samme type dæmpende effekt opstår, når der er tendens til målefejl på den uafhængige variabel (se King, Keohane, and Verba, 1994: kap. 5). Hverken deltagelse i forelæsninger eller selvstændigt arbejde med øvelser måles helt præcist i undersøgelsen, og selvrapporteret angivelse af forberedelsestid er i sagens natur også behæftet med en vis usikkerhed. Det er således meget sandsynligt, at effekterne af de forskellige former for studieaktivitet er stærkere end de, som kan observeres her.

\section{Konklusion}

Analysen har søgt at besvare to spørgsmål, som er relevante for alle, som planlægger kurser, som ikke hører til de mest populære blandt de studerende. Det første var, hvilke effekter man kan forvente af generelle pædagogiske forbedringer af et kursus. Analysen viste ret entydigt, at ændringerne havde en klar effekt på de studerendes tilfredshed, også selv om der knytter sig usikkerhed til det præcise omfang af effekten som følge af de beskrevne problemer med stikprøven. Effekten på eksamenspræstationerne var også tydelig. Effekten var dog ikke generel, men stærkt polariseret. Man kunne observere et gennemsnitligt løft i det faglige niveau, men effekten på de bedste to tredjedele af de studerende (som bestod) var markant højere end på den dårligste tredjedel (som ikke bestod). Den relativt lave studieaktivitet, som de studerende selv rapporterede, og den, som kunne observeres på kursets hjemmeside, indikerede, at en del af problemet kunne ligge her. I undersøgelsen af hvilke specifikke studieaktiviteter - forberedelsestid, deltagelse i forelæsninger og selvstændigt arbejde med øvelser - der er væsentlige for den individuelle læring, viste det sig således også, at selvstændigt arbejde med øvelsesmaterialet havde den stærkeste effekt, mens deltagelse i forelæsningerne også var positivt og signifikant korreleret med præstationerne. Forberedelsestid betød dog ikke det samme for alle og var kun svagt positivt korreleret med eksamenspræstationen, og resultatet var ikke signifikant. Forudsætningerne og evnerne til at sætte sig ind i stoffet varierer utvivlsomt betydeligt, og behovet for løbende at forberede sig til undervisningen er således ikke overraskende forskelligt fra person til person. Analysen viste dog tydeligt, at forberedelsestiden ikke har en lineær sammenhæng med eksamensresultatet: forberedelse over fem timer om ugen eliminerede så godt som alle de dårlige præstationer og viste sig at være tilstrækkeligt til at bestå. Hvis man således skal imødegå udfordringen med at få flere til at bestå eksamen, er det ikke tilstrækkeligt at ændre på selve kurset. Der skal tilsyneladende arbejdes med at motivere de studerende til at følge undervisningen - særligt arbejde med øvelserne - og særligt for de, som har vanskeligt ved stoffet, skal der bruges mere tid på forberedelse. 
Carina S. Bischoff (ph.d.) er studieleder og lektor på Institut for Samfund og Globalisering på Roskilde Universitet. Hendes forskningsinteresser ligger inden for feltet komparativ politik, hvor hun har beskæftiget sig med spørgsmål relateret til partier og partisystemer, valg, valgsystemer og vælgeradfærd såvel som den Europæiske Union. Hun underviser i politologiske fag såvel som metode, primært kvantitativ.

\section{Litteratur}

Biggs, J. (2003). Teaching for quality learning at University (2nd ed.). London: The Society for Research into Higher Education \& Open University Press.

Biggs, J. \& Tang, C (2011). Teaching for Quality Learning at University: What the Student Does (4. ed.). Berkshire: Open University Press.

Collier, David \& James Mahoney (1996): Insights and Pitfalls: Selection Bias in Qualitative Research. World Politics 49(1) pp. 56-91.

Dehaan, R. (2005). The Impending Revolution in Undergraduate Science Education. Journal of Science Education and Technology, Vol. 14, No. 2, June 2005.

Dyrberg O'Neill, L., Vonsild, M. C. \& B. Wallstedt (2013). Kvote 2-optagelse of akademiske præstationer: Hvor stor betydning har det adgangsgivende eksamenssnit? Dansk Universitetspædagogisk Tidsskrift. Årgang 8, nr. 14. s. 8699.

Gerring, John (2004). What is a Case Study and What is it Good For? American Political Science Review 98(2). pp. 341-354 (14 sider).

Herrmann, K.J., Bager-Elsborg, A., Borch Hansen, I. og R. Nielsen (2015). Mere undervisning, større studieintensitet? En multilevelanalyse af 7.917 studerendes tidsforbrug. Dansk Universitetspædagogisk Tidsskrift. Årgang 10, nr. 17. s. 35-50.

Kember, D. \& Leung, D.Y.P. (1998). Influences upon students' perceptions of workload, Educational Psychology, 18, pp. 293-307.

King, G.; , R. O.; Keohane, and S. Verba. 1994. Designing social inquiry. Scientific inference in qualitative research. In. Princeton: Princeton University Press.

Lizzio, A. Wilson, K. \& R. Simons (2002). University Students' Perceptions of the Learning Environment and Academic Outcomes: implications for theory and practice. Studies in Higher Education, Volume 27, No. 1. s. 27-52

Qvortrup, A. \& Keiding, T. B. (2014). Undervisningens vidensdomæner: erfaring, didaktik og uddannelsesvidenskab. Dansk Universitetspædagogisk Tidsskrift. Årgang 9, nr. 17. s. 6-19. 